\title{
Critical Discourse Analysis of Translation Techniques on Text of Webtoon
}

\author{
Dyan Pratiwi Kusumaningtyas \\ Applied Linguistics Departement \\ Yogyakarta State University \\ Yogyakarta, Indonesia \\ diiy.pratiwi@gmail.com
}

\author{
Teguh Setiawan \\ Applied Linguistics Departement \\ Yogyakarta State University \\ Yogyakarta, Indonesia \\ teguh_setiawan@uny.ac.id
}

\begin{abstract}
The translation quality results will look natural if the translation able to produce in accordance with the target language (TL). But in order to achieve this, the translator is able to adapt to the social and cultural context of the source language (SL). In this article reveals the translations used by translator and also analyzed them used. This research is descriptive qualitative by referring the concept of Vinay and Dabernet in determining the translation techniques used and also refers to the theory of Fairclough in analyzing the critical discourse analysis. Sources data in this research is "Eggnoid" webtoon reflects the expressive text that will be thick for the use of language typical of Indonesian people especially teenagers and the translation in English. While the data collection used by the observe method then used advanced techniques there is SLBC (simak libat bebas cakap) techniques and then last used record to analyze the data.
\end{abstract}

Keywords-critical discourse analysis; intertextual meaning; translation

\section{INTRODUCTION}

Social and cultural contexts are one of the most important elements to be observed by a translator in order to create a translated text that can be enjoyed by the target language reader. Translating is not just transfer language to another language but producing good quality cannot be separated from the translator's role to translate the meaning and aesthetic elements including in this case is the style of language. In the process of translation, the translator often encounters problems. Translation technique are needed to solve these problems. Translation techniques are the means used to divert messages from SL to TL, applied to words, phrases, clauses or sentences. Molina and Albir [1, p. 509], translation techniques have five basic characteristics: (1) they affect the result of the translation, (2) they are classified by comparison with the original, (2) they affect micro-units of text, (3) they are by nature discursive and contextual, (4) they are functional. Based on that context, this research tries to reveal the meaning change as well as the translation technique used by webtoon translator in translating text which has social and cultural as well as cultural element in the use of typical language style reflects Indonesian teenager's conversation style. Critical Discourse Analysis is considered the most appropriate use in revealing the text changes related to social and cultural elements. Critical Discourse Analysis is an approach in analyzing texts and their relation to socio-cultural practices [2, p. 7]. In the Critical Discourse Analysis, discourse is not only seen as something that is formed, but also be formed. Fairclough argues that Critical Discourse Analysis views discourse as text, discourse practice and social practice. Still, according to Fairclough, using Critical Discourse Analysis to examine texts is an attempt to understand changes in social practices and cultural change. A text may potentially change into different forms at different times because it is influenced by social, political and cultural contexts.

\section{REVIEW OF LITERATURE}

\section{A. Critical Discourse Analysis}

Critical Discourse Analysis is an approach in analyzing texts and their relation to socio-cultural practices [2, p. 7]. At the same time, discourse is also shaped by other social practices and structures. Thus, discourse has a dialectical relationship with social dimension. As Critical Discourse Analysis is interested in dismantling the representation of social reality in discourse, Fairclough and Wodak in van Dijk [3, pp. 258-284] further elaborates the principles of Critical Discourse Analysis doctrine as follows: (1) discussing social issues, (2) power relations, (3) revealing culture and society, (4) raising the relationship between text and society, (5) is interpretive and explanatory. Characteristics of critical discourse analysis vary widely according to experts. From the writings of van Dijk [3], Fairclough, Fairclough \& Wodak, and Eriyanto, the following is the essence of AWK characteristic clarity i.e, (1) action, (2) context, (3) historical, (4) powers, and (5) ideologies.

\section{B. Translation}

Translation is the process of moving a language into another language. The transfer process is done by transferring a language into the target language. As the times progressed, the journey of definitions and theories of translation experienced some construction in its understanding and technique. The construction is done by translator experts to facilitate the translation process in accordance with the evolving circumstances, but the estuary of the translation is to divert. This is in line with Catford's opinion [4, p. 20], which describes Translation may be defined by the equivalent textual material in another language. Whereas Hatim and Munday [5, p. 6] have similarities in defining translation as "a) The process of a translating text from SL to TL, conducted by translators, or translators, in a specific sociocultural context; 
b) which result from that process and which functions in the socio-cultural context of the TL; c) The cognitive, linguistics, visual, cultural and ideological phenomena which are an integral part of 1 and 2 ". Then, Newmark [6, p. 5] in his book "A Textbook of Translation" said that : "Though not by any means always, it is rendering the meaning of a text into another language in the way that the author intended the text.”

\section{Translation Tecnique}

In the process of translating there are certain techniques performed by a translator, the technique helps an interpreter to simplify the process of translation. In this study the researchers used a technique introduced by Vinay and Dabernet in 1958. Vinay and Dabernet introduced a translation technique which he called the translation procedure. The wide spread of the translation procedure has had an enormous impact, Vinay and Dabernet analyzed the comparative stylists of French and English using seven translation procedures grouped into two methods namely direct translation and indirect translation methods. The following is a grouping of translation procedures according to Vinay and Dabernet in Venuti [7, p. 84].

TABLE I. TRANSLATION PROCEDURES VINAY AND DABERNET IN VENUTI.

\begin{tabular}{|c|c|}
\hline \multicolumn{2}{|r|}{ Direct Translation } \\
\hline $\begin{array}{l}\text { Borrowing } \\
\text { Calque } \\
\text { Literal }\end{array}$ & $\begin{array}{l}\text { A word taken directly drom another } \\
\text { languages } \\
\text { A foreign word or phrase translated and } \\
\text { Incorporated into another language. } \\
\text { Word for word translation. }\end{array}$ \\
\hline \multicolumn{2}{|r|}{ Oblique Translation } \\
\hline Transposition & $\begin{array}{l}\text { A shift of word class, i.e., verb for noun, } \\
\text { noun for preposition. }\end{array}$ \\
\hline Modulation & $\begin{array}{l}\text { A shift in point of view. Whereas } \\
\text { transposition is a shift between } \\
\text { gramatical categories, modulation is a } \\
\text { shift cognitive categoris. There are } \\
\text { eleven tyes of modulation: abstract for } \\
\text { concrete, cause for effect, means for } \\
\text { result, a part for the whole, geographical } \\
\text { change. }\end{array}$ \\
\hline Equivalence & $\begin{array}{l}\text { This accounts for the same situation } \\
\text { using a completely different phrase. }\end{array}$ \\
\hline Adaptation & A shift in cultural environment. \\
\hline
\end{tabular}

\section{Research Methodology}

This research is a qualitative research and library research. In qualitative descriptive research the researcher produces an in-depth description of speech, writing, as well as behavior that can be observed in an individual. Qualitative research is used to get a data in depth, in these data contain a meaning, therefore qualitative research guided by the facts found at the time of field research.

The data source in this study is a webtoon entitled "Eggnoid" chapter 1 to chapter 5 in Indonesian and also in
English translation. The data in this study is the Indonesian text as well as the English translation in the "Eggnoid" webtoon from chapter 1 until chapter 5. "Eggnoid" is one of the Indonesian webtoons by Archie The Red Cat which has been translated into 18 foreign languages including one is English. The translator is 53 translator contributors who are the webtoon enthusiasts of "Eggnoid".

The technique used in this research refers to the technique proposed by Sudaryanto [8, p. 207] that is using the method of referring then using advanced technique of record technique. The method used in this research is done by observing the translation technique used by translator "Eggnoid" in translating it into English. The advanced technique used is the SLBC (simak libat bebas cakap) technique its means the authors are not directly involved in determining the formation and appearance of data so that researchers only act as observers of data formed and emerged from linguistic events that are outside the author, then proceed using techniques record.

Referring to Nasution in Sugiyono, the main instrument of this study is the researchers themselves, because researchers play an important role as a data observer as well as understand the data. That is, the theory understood by the researcher is used as a research instrument. The analysis in this research is done by qualitative descriptive method. Researchers refer to the theory of Nasution, Sudaryanto [8]. Nasution in Sugiyono states "Analysis began since the beginning of the formulated and explained the problem, before going into the field, and lasted until writing of research results". Then referring from Sudaryanto [8, pp. 17-18], this research uses a method of translational equivalent (padan translasional) which in this study using another language to identify the language unit of the language being studied. Which is then outlined to explain its relevance to the role of translator to pay attention to the social and cultural context in the process of translating texts.

\section{RESULT AND DISCUSSION}

\section{A. Result}

Data in "Eggnoid" webtoon chapter 1 through chapter 5 are 236 in both Indonesian and English. After the data were analyzed the most frequently used technique in translation of Eggnoid webtoon was literal technique with 121 data using the technique, then 62 data using transposition technique, 35 data using modulation technique, 10 data using adaptation, 3 data using technique calque, 3 data also which uses the equivalence technique, and 1 data using the borrowing technique.

The data source is a text that has elements of social and cultural context of Indonesia. Some texts even use terms that are often spoken by Indonesians. However, the data obtained show that translators prefer to use a literal translation in which literal translation is a translation done by translating verbatim in sentences. Here are some examples of literal translation found in the data. 
TABLE II.

DATA ANALYSIS OF LITERAL TRANSLATION TECHNIQUES

\begin{tabular}{|l|l|}
\hline \multicolumn{1}{|c|}{ SL } & \multicolumn{1}{|c|}{ TL } \\
\hline $\begin{array}{l}\text { Orang bilang masa SMA } \\
\text { adalah masa yang paling } \\
\text { indah. }\end{array}$ & $\begin{array}{l}\text { People say that high school is } \\
\text { the most beautiful moment } \\
\text { ever. (chapter 1 data 2) }\end{array}$ \\
\hline $\begin{array}{l}\text { aku lupa kamu belum punya } \\
\text { baju! }\end{array}$ & $\begin{array}{l}\text { I forgot you don't have } \\
\text { clothes (chapter 2 data 99) }\end{array}$ \\
\hline $\begin{array}{l}\text { Terus jangan panggil aku } \\
\text { mama melulu namaku kirana. }\end{array}$ & $\begin{array}{l}\text { Also, stop calling me mama. } \\
\text { My name is kirana (chapter 3 } \\
\text { data 139) }\end{array}$ \\
\hline
\end{tabular}

Some other data as well as the above data, where the translator prefers to translate words. It can be seen in the data that SL and TL are literal translations that are more directed to SL than to TL. This type of translation is considered the closest to SL. The order of words in the source language text is retained, words are translated according to their basic meaning out of context. Word-by-word translation is useful for interpreting difficult texts as the beginning of translation, but this translation is very incompatible with expressive text because it will tend to be rigid for the target language.

Furthermore, there is a transposition technique that occupies the second position of the most widely used translator in translating webtoon Eggnoid. The technique of transposition translation is a translation technique that changes the order of words in sentences and its main feature is the conversion of the verb type word instance into a noun and the other. Here are some translation data using transposition translation techniques.

TABLE III. DATA ANALYSIS OF TRANSPOSITION TRANSLATION TECHNIQUES

\begin{tabular}{|l|l|}
\hline \multicolumn{1}{|c|}{ SL } & \multicolumn{1}{|c|}{ TL } \\
\hline $\begin{array}{l}\text { Kalau begitu ayok kita juga } \\
\text { pergi jalan-jalan! }\end{array}$ & $\begin{array}{l}\text { Then we'll also go have fun! } \\
\text { (chapter 2 data 91) }\end{array}$ \\
\hline $\begin{array}{l}\text { udah dibilang kan jangan } \\
\text { jauh-jauh. }\end{array}$ & $\begin{array}{l}\text { I already warned you not to } \\
\text { go too far! (chapter 4 data } \\
162 \text { ) }\end{array}$ \\
\hline
\end{tabular}

Then there are 35 data using modulation translation techniques. The translator uses a modulation technique to translate a text by changing the viewing angle but retaining the message in the source language text. Here are some data using modulation translation techniques.

TABLE IV. DATA ANALYSIS OF MODULATION TRANSLATION TECHNIQUES

\begin{tabular}{|l|l|}
\hline \multicolumn{1}{|c|}{ SL } & \multicolumn{1}{|c|}{ TL } \\
\hline Tidaaaakk, apa-apaan ini?! & $\begin{array}{l}\text { Nooooo!!! What the hell is } \\
\text { happening?! (chapter 2 data } \\
59)\end{array}$ \\
\hline Lelah hati ini & My heart (chapter 2 data 85) \\
\hline Jangan-jangan & $\begin{array}{l}\text { What if...!! (chapter 3 data } \\
182)\end{array}$ \\
\hline
\end{tabular}

In data using modulation techniques more often found in expressive action text, such as data above. The data show expressive texts that are often used in expressing annoyance, but in the target language the translator prefers to use another translation according to the interpreter's perspective but still within the message context.

There are 10 data using adaptation techniques. Adaptation technique is a translation technique by replacing text in accordance with target language culture. Translators typically use this technique to replace text that is inconsistent with the social and cultural context in the target language. The "Eggnoid" webtoon translator himself often uses adaptation techniques to adjust the target language culture because there are some source language texts that do not match the target language. Here are some data that use adaptation translation techniques.

TABLE V. DATA ANALYSIS OF ADAPTATION TRANSLATION TECHNIQUES

\begin{tabular}{|c|l|}
\hline \multicolumn{1}{|c|}{ SL } & \multicolumn{1}{|c|}{ TL } \\
\hline Gyahhh pusing pala berbi! & $\begin{array}{l}\text { Gaaahhhh! This is makes me } \\
\text { dizzy what should I do? } \\
\text { (chapter 3 data 115) }\end{array}$ \\
\hline
\end{tabular}

The above data shows the source language text is quite familiar texts often used by Indonesian youth, so translators translate by taking other contexts that still reflect the message of the source language but in accordance with the social and cultural context of LT.

There are 3 data using the equivalence technique and calque technique respectively. Both techniques are rarely used by translators in translating webtoon "Eggnoid". Here are some data that use equivalence techniques.

TABLE VI. DATA ANALYSIS EQUIVALENT TRANSLATION TECHNIQUES

\begin{tabular}{|l|l|}
\hline \multicolumn{1}{|c|}{ SL } & \multicolumn{1}{|c|}{ TL } \\
\hline $\begin{array}{l}\text { Teryata aku adalah korban } \\
\text { *PHP! } \\
\text { *pemberi harapan palsu. }\end{array}$ & $\begin{array}{l}\text { I was a victim of a one-sided } \\
\text { relatioship! }\end{array}$ \\
& $\begin{array}{l}\text { *original indonesia term } \rightarrow \\
\text { PHP mentioned to a people } \\
\text { who give a fake hope. } \\
\text { (chapter 1 data 6) }\end{array}$ \\
\hline Dasar bandel ! & $\begin{array}{l}\text { Stop being such a stone head! } \\
\text { (chapter 4 data 161) }\end{array}$ \\
\hline
\end{tabular}

Equivalent technique is used by matching the SL text with TL. Although not in accordance with the SL but this technique is concerned with the TL as a reference in translating, so that the reader of the text of the translation can understand the meaning of the SL. As in the data above that shows the author webtoon "Eggnoid" using slang language that is quite familiar to teenagers Indonesia to more interesting webtoonnya, but if translated translator using pendeskripsian or other equivalent text. 
TABLE VII. DATA ANALYSIS OF CALQUE TRANSLATION TECHNIQUES

\begin{tabular}{|l|l|}
\hline \multicolumn{1}{|c|}{ SL } & \multicolumn{1}{|c|}{ TL } \\
\hline Orang tua asuh? & $\begin{array}{l}\text { Foster parents? (chapter 2 } \\
\text { data 68) }\end{array}$ \\
\hline
\end{tabular}

There is 1 data using borrowing technique. Borrowing technique itself is a translation technique done by taking the source language into a translation for the target language. In translating the "Eggnoid" webtoon the translator uses only borrowing techniques to translate the word "dibungkus" in chapter 2 data number 80 . Translators use the word "dibungkus" in the target language translation.

\section{B. Discussion}

The overarching goal of this study is to find translation techniques used by the "Eggnoid" webtoon translator whose source language itself is a language that reflects the context of Indonesia's social and cultural reality. There were 121 data using the technique, then 62 data using transposition technique, 35 data using modulation technique, 10 data using adaptation, 3 data using calque technique, 3 data also using equivalence technique, and 1 data using borrowing technique.

Translators are more likely to use literal translation techniques. The translator translates verbatim in expressive texts that contain the social and cultural elements of the source language. So, the impression in the text is more likely to lead to the source language rather than the target language. No doubt if comments from some foreign readers are confused with the storyline as well as the use of the language used.

Webtoon is a web comic that has been in demand by various age groups. Not only from the country of origin of Korea, but also many countries have installed webtoon applications to enjoyed times. "Eggnoid" is one of the webtoon from Indonesia which became one of the favorite webtoon because it presents an interesting story with storyline as well as language style which is suitable with Indonesian teenagers. The choice of expressive language and easy to understand Indonesian readers. So very unfortunate if the webtoon gets a negative predicate just because the form of translation that does not match the target language.

\section{CONCLUSION}

Translation techniques are a solution for translators in translating a text. There are several choices of translation techniques that translators can use to improve the quality of their translation. The translation techniques themselves can also assist translators in translating very closely source language texts with elements of the social and cultural context of reality with the application of equivalent or adaptation techniques to add the quality of translation results in accordance with the target language. It is hoped that with the good quality of the translations it makes it easier for target language readers to better understand and enjoy the mesh of the story.

In this paper, researchers make connected critical discourse analysis with translation techniques that specifically address the various techniques used to translate a text. To further extend and deepen this discussion, the authors suggest to include other analytical studies as well as text analysis with images that will add to the diversity of analysis results.

\section{REFERENCES}

[1] Molina, Lucia, and H. Albir, "Translation Techniques Revisited: A Dynamic and Functionalist Approach,” Meta: Journal des Traducteur/Meta: Translat. J., vol. 47, no.4 , pp. 498-512, 2002.

[2] N. Fairclough, Norman. Critical Discourse Anlysis. New York: Longman Group Ltd., 1995.

[3] van Dijk, Discourse as social interaction. London : Sage, 1997.

[4] J. C. Catford, A Linguistic Theory of Translation. Oxford: Oxford University Press, 1965.

[5] B. Hatim and J. Munday, Translation : An Advanced Resources Book. London : Routledge, 2004.

[6] P. Newmark, A Textbook of Translation. London: Prentice Hall Internation Ltd., 1988.

[7] L. Venuti, The Translation Studies Reader. London : Routledge, 2000.

[8] Sudaryanto. Metode dan Aneka Teknik Analisis Bahasa [Methods and Various Techniques of Language Analysis]. Yogyakarta: Sanata Dharma University Press, 2015. 